\title{
ОПТИМІЗАЦІЯ РОЗМЩЩЕНЯ ПРИЙМАЧІВ СОНЯЧНОЇ ЕНЕРГІЇ РЯДАМИ ДЛЯ КЛІМАТИЧНИХ УМОВ ПІВДНЯ УКРАЇНИ
}

\author{
О.В. Андронова, канд. техн. наук, В.В. Курак, канд. техн. наук
}

Херсонський національний технічний університет,

73008, Бериславське шосе, 24, м. Херсон, Україна.

Максимальне надходження сонячної енергії на поверхню приймачів при їх розміщенні паралельними рядами забезпечується мінімізацією затінення одного ряду іншим. Існуючі методики розрахунку надходження сонячної радіації до приймачів в умовах затінення рядами не дають універсальної відповіді на питання щодо оптимального взаєморозтамування рядів сонцесприймальних поверхонь і потребують залучення даних щьоо умов сонячної інсоляції для конкретної місцевості. Оскільки методики, щз базуються на розрахунку абсолютних показників з надходження енергії до поля приймачів, потребують, окрім енергетичних, додаткових критеріїв оптимізаџї, то варто орієнтуватися на показники з надходження сонячної радіації на одиницю площі сонщесприймальної поверхні, яка затінюється.

Метою даної роботи є розрахунок надходження сонячної радіації на одиниџю площчі сонцесприймальної поверхні частково затіненого ряду та визначення оптимальних параметрів розміщення приймачів паралельними рядами для кліматичних умов півдня України.

Представлено методику розрахунку надходження сонячної енергії на частково затінені ряди, щяо враховує пряму, дифузну, відбиту сонячну радіацію від підстилаючої поверхні та нахиленої поверхні приймачів. Для кліматичних умов м. Херсона отримано вирази, що дозволяють в зручний спосіб без проведення громіздких розрахунків визначити річну питому енергію, яка надходить на одинищю площі затіненого ряду при заданому куті нахилу поверхні та відстані між рядами. Показано, що в якості оптимального кута положення, який визначає відстань між рядами приймачів, доцільно прийняти кут висоти Сония у сонячний полудень 21 грудня. Визначено оптимальний кут нахилу поверхні приймачів, що забезпечує максимальне річне надходження сонячної радіації на одинищю площі сонщесприймальної поверхні затіненого ряду.

Розраховано параметри розміщення приймачів паралельними рядами для інших міст півдня Украйни та визначено середні значення оптимальних кутів положення та нахилу сонцесприймальної поверхні. Бібл. 8, табл. 8, рис. 4.

Ключові слова: сонячна радіачія, затінення, кут нахилу, відстань між рядами.

\section{OPTIMIZATION OF ROW PLACEMENT OF SOLAR ENERGY COLLECTORS FOR THE CLIMATIC CONDITIONS OF THE SOUTH OF UKRAINE}

O. Andronova, candidate of technical science, V. Kurak, candidate of technical science

Kherson National Technical University,

73008, 24 Beryslavske shose, Kherson, Ukraine.

The maximum amount of solar energy falling on the surface of multiple collector rows occurs when effect of shading one row by another is negligible. The existing methods for calculating of incident solar radiation on collector planes under conditions of shaded rows are not capable to give a universal answer about the optimal placement of rows for any place, and data on solar insolation for particular location are required for optimization. Since the methods based on the calculation of absolute solar energy falling on the whole collector field require additional non-energy criteria of optimization, it is necessary to focus on solar radiation per unit area of shaded collector.

The aim of this work is to calculate incident solar radiation per unit area of a partially shaded collector row and to determine the optimal parameters of multiple row placement of collectors for the climatic conditions of the south of Ukraine.

A method for calculating of incident solar energy for the case of partially shaded collector row taking into account direct and diffuse solar radiation as well as radiation reflected from the underlying base and inclined collector surfaces is presented. Expressions for the annual incident solar energy per unit collector area of the shadowed row depending on the tilt angle and the distance between the rows have been obtained for the climatic conditions of Kherson. These expressions make it possible to avoid cumbersome calculations when the data on annual incident energy under conditions of shading are needed. It is shown that the optimal position angle, which determines the distance between the collector rows, is the angle of the Sun height at solar noon on December 21. The optimal tilt angle of collectors that provides the maximum annual solar radiation per unit area of the shaded collector row has been determined.

Parameters of the multiple row placement of collectors have been calculated for the climatic conditions of other cities of the south of Ukraine and the average values of optimal position angle and optimal tilt angle of collectors were determined. Ref. 8, tab. 8, fig. 4. Keywords: solar radiation, shading, tilt angle, distance between the rows. 


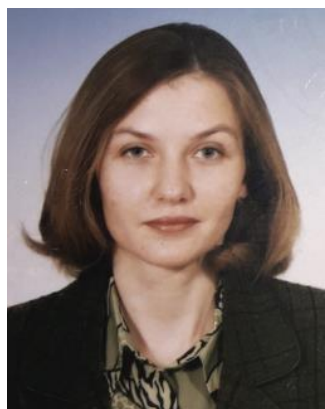

О.В. Андронова

O. Andronova

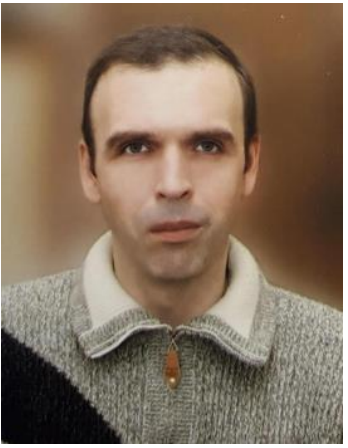

B.B. Курак

V. Kurak
Відомості про автора: доцент кафедри енергетики, електротехніки і фізики Херсонського національного технічного університету, доцент, кандидат технічних наук.

Освіта: Херсонський державний технічний університет, факультет

Кібернетики.

Наукова сфера: геліоенергетика, термофотовольтаїка, енергозбереження в будівлях.

Публікації: понад 80, з них 29 статей та 6 патентів.

ORCID: 0000-0001-9597-8068

Контакти: тел.: +38 (067) 745-77-81

e-mail: kev_ku@ukr.net

Відомості про автора: доцент кафедри енергетики, електротехніки і фізики

Херсонського національного технічного університету, доцент, кандидат технічних наук.

Освіта: Херсонський індустріальний інститут, факультет кібернетики.

Наукова сфера: фотовольтаїка, технологія матеріалів для напівпровідникових фотоелектричних перетворювачів.

Публікації: понад 80, з них 35 статей та 5 патентів.

ORCID: 0000-0002-4303-5671

Контакти: тел.: +38 (097) 221-02-90

e-mail: vk_74@ukr.net
Author information: associate professor of the Department of Power, Electrical Engineering and Physics of the Kherson National Technical University, associate professor, candidate of technical science. Education: Kherson State Technical University, Faculty of Cybernetics. Reasearch area: solar energy, thermophotovoltaics, energy saving in buildings Publications: over 80, including 29 articles and 6 patents.

ORCID: 0000-0001-9597-8068

Contacts: phone: +38 (067) 745-77-81

e-mail: kev_ku@ukr.net

Author information: associate professor of the Department of Power, Electrical

Engineering and Physics of the Kherson National Technical University, associate professor, candidate of technical science. Education: Kherson Industrial Institute, Faculty of Cybernetics.

Reasearch area: photovoltaics, technology of materials for semiconductor solar cells.

Publications: over 80, including 35 articles and 5 patents.

ORCID: 0000-0002-4303-567

Contacts: phone: +38 (097) 221-02-90

e-mail: vk_74@ukr.net

Перелік використаних позначень та скорочень:

$a_{l}$ - альбедо підстилаючої поверхні;

$D$ - відстань між рядами приймачів;

$d$ - відносна відстань між рядами приймачів;

$F_{H-g r d, s}$ - коефіцієнт положення поверхні приймача відносно затіненої підстилаючої поверхні;

$F_{H-g r d, u s}-$ коефіцієнт положення приймача відносно незатіненої підстилаючої поверхні;

$F_{H-H}-$ коефіцієнт положення приймача відносно тильної поверхні попереднього ряду;

$F_{H-s k y}$ - коефіцієнт положення поверхні приймача відносно неба;

$G$ - річне надходження сонячної енергії на одиницю площі сонцесприймальної поверхні ряду;

$G_{\max }$ - максимальне річне надходження сонячної енергії на сонцесприймальну поверхню;

$H$ - висота приймача;

$H_{S}$ - висота тіні на сонцесприймальній поверхні;

$h_{s}$ - відносна висота тіні;

$I_{b h}$ - пряма годинна сонячна радіація, що надходить на горизонтальну поверхню;

$I_{d h}$ - дифузна годинна сонячна радіація, що надходить на горизонтальну поверхню;

Вступ. Досягнення високих потужностей генерації від систем на основі фотоелектричних перетворювачів та теплових сонячних
$I_{h}$ - сумарна годинна сонячна радіація, що надходить на горизонтальну поверхню;

$I_{T}$ - сумарна годинна сонячна радіація, що надходить на нахилену поверхню;

$I_{\beta}$ - повна годинна сонячна радіація на нахилену поверхню Приймача;

$L$ - довжина ряду приймачів;

$L s$ - довжина тіні на сонцесприймальній поверхні;

$l$ - відносна довжина ряду приймачів;

$l_{s}$ - відносна довжина тіні;

$R_{b}$ - коефіцієнт перерахунку прямої сонячної радіації з горизонтальної на нахилену поверхню;

$r e f$ - коефіцієнт відбиття від поверхні приймача;

$S$ - довжина тіні від приймача на горизонтальній поверхні на поточну годину;

$s$ - фактор затінення;

$\alpha$ - кут висоти Сонця;

$\beta$ - кут нахилу сонцесприймальної поверхні;

$\beta_{\text {опт }}$ - оптимальний кут нахилу сонцесприймальної поверхні;

$\gamma_{s}$ - кут азимуту Сонця;

$v$ - кут положення сонцесприймальної поверхні;

$v_{\text {опт }}-$ оптимальний кут положення сонцесприймальної поверхні.

колекторів вимагає задіяння великих площ геліополя, що пов'язано з порівняно невисокою щільністю енергетичного потоку некон- 
центрованого сонячного випромінювання. Обмеженість площі розміщення приймачів сонячного випромінювання викликає необхідність розташування перетворювачів паралельними рядами (так зване килимове розміщення), що неминуче призводить до виникнення проблеми затінення сонцесприймальних поверхонь сусідніми рядами (рис. 1).
Для забезпечення максимального надходження сонячної енергії на приймальну поверхню при килимовому розміщенні приймачів необхідно мінімізувати негативний вплив затінення рядів, зокрема, шляхом оптимізації таких параметрів, як кут нахилу сонцесприймальної поверхні $\beta$ та відстань між рядами $D$.

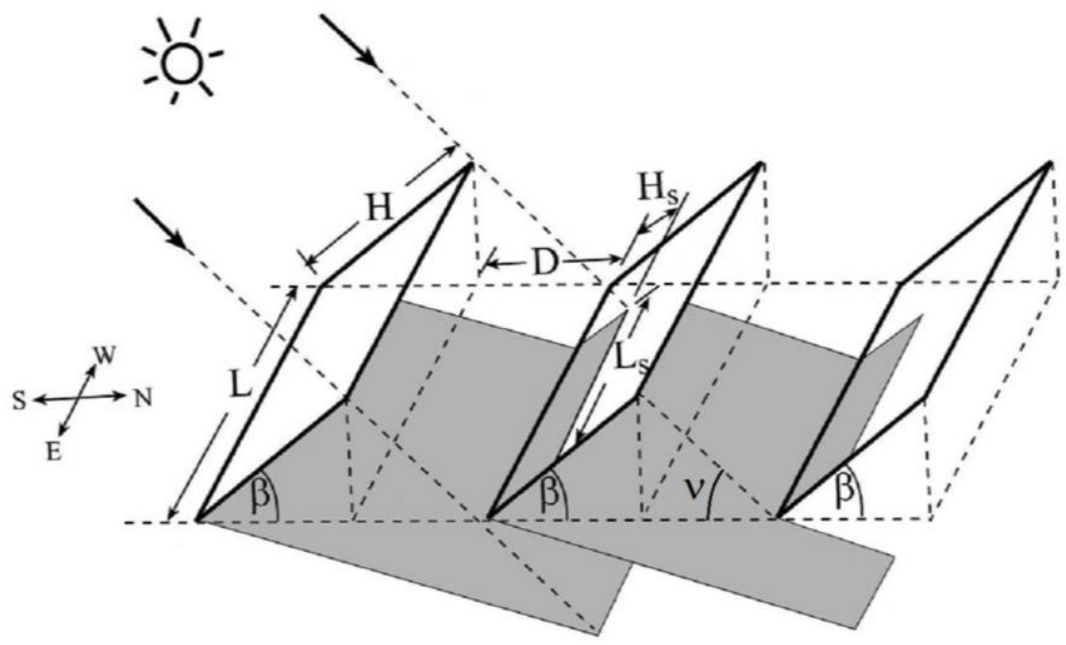

Рис. 1. Затінення приймачів при розташуванні рядами.

Fig. 1. Shading of multiple row placed collectors.

Так в роботах $[1,6]$ для визначення середньомісячної добової сонячної радіації (ізотропна модель Ліу-Джордана), що надходить на частково затінену поверхню приймачів, введено фактор затінення для прямої радіації та модифіковано коефіцієнти положення для дифузної та відбитої радіації, що враховують широту місцевості, годину дня, відстань між рядами та габарити приймачів. Результати розрахунків показали, що у випадку необмеженої площі розташування приймачів зі зростанням відстані між рядами надходження сонячної радіації на затінену сонцесприймальну поверхню збільшується, і ця залежність виходить на насичення, тому для оптимального розташування приймачів рядами запропоновано застосовувати не енергетичні, а економічні критерії.

В [11] запропоновано використовувати фактор незатінення для дифузної й відбитої сонячної радіації, що визначається нахилом поверхні й відстанню між рядами, та фактор незатінення для прямої радіації, що залежіть також і від висоти Сонця над горизонтом. Оптимальними приймаються розташування приймачів, при яких фактори незатінення становлять не менше 95\% від свої максимальних значень, що дозволяє знайти діапазон відстаней між рядами при певному куті нахилу сонцесприймальної поверхні.

Для розрахунку надходження сонячної радіації в умовах взаємного затінення сонцесприймальних поверхонь в [7] запропоновано модифіковані коефіцієнти положення приймача відносно неба та підстилаючої поверхні, а також додатково враховано відбиття від тильної поверхні попереднього ряду введенням відповідного коефіцієнту.

Доволі широкого використання набула методика [4], в якій для розрахунку надходження прямої складової випромінювання використовується фактор затінення, а дифузної складової - модифікований коефіцієнт положення. Фактор затінення враховує азимут приймальної поверхні, кут висоти Сонця, широту місцевості, кут нахилу поверхонь та відстань між рядами, а коефіцієнт положення - тільки останні два параметри. На основі розрахунку надходження сонячної радіації за цією методикою проведено оптимізацію поля фотоелектричних перетворювачів в умовах обмеженої площі розміщення $[3,9,10]$. По- 
казано, що максимальне надходження сонячної енергії досягається при мінімальній відстані між рядами приймачів і відповідному збільшенні їх кількості, тому додатково введено обмеження мінімальної відстані, при якій і визначено оптимальні кути нахилу поверхонь для умов Тель-Авіву.

Таким чином, єдиної загальноприйнятої методики розрахунку надходження сонячної радіації на сонцесприймальну поверхню в умовах затінення рядів не існує. Методики, що базуються на розрахунку абсолютних показників 3 надходження енергії до поля приймачів, не дозволяють отримати чіткі значення оптимальних параметрів розташування i потребують залучення додаткових критеріїв оптимізації. Тому варто орієнтуватися на питомі енергетичні показники, як-то надходження сонячної радіації на одиницю площі сонцесприймальної поверхні, що частково затінюється. При цьому доцільно враховувати не лише пряму та дифузну складові сонячного випромінювання, але й відбите від підстилаючої поверхні та тильної поверхні попереднього ряду. Крім того, оптимізація параметрів килимового розташування приймачів повинна проводитись для умов сонячної інсоляції конкретної місцевості, що обумовлюється використанням в даних методиках не тільки характерних кутів, що описують положення сприймаючої поверхні відносно Сонця, але й інформації стосовно прямої та дифузної складових сонячного випромінювання, альбедо підстилаючої поверхні, що $\epsilon$ суто характеристиками місця розташування.

Постановка завдання. Метою даної роботи є розрахунок надходження сонячної радіації на одиницю площі сонцесприймальної поверхні частково затіненого ряду та визначення оптимальних параметрів розміщення приймачів паралельними рядами для кліматичних умов півдня України.

Виклад основного матеріалу дослідження. Повна годинна сонячна радіація $I_{\beta}$, що надходить на частково затінену поверх- ню, розраховувалась як сума прямої $I_{b h}$, дифузної $I_{d h}$, відбитої радіації від підстилаючої поверхні $a_{l} I_{h}$ та від нахиленої поверхні приймача $r e f I_{T}$, помножених на відповідні коефіцієнти положення $F$ :

$$
\begin{gathered}
I_{\beta}=I_{b h} R_{b}(1-s)+F_{H-s k y} I_{d h}+ \\
+a_{l}\left(F_{H-g r d, s} I_{d h}+F_{H-g r d, u s} I_{h}\right)+\operatorname{ref} F_{H-H} I_{T},
\end{gathered},
$$

де $R_{b}$ - коефіцієнт перерахунку прямої сонячної радіації з горизонтальної на нахилену поверхню [5]; $s$ - фактор затінення; $a_{l}$ - альбедо підстилаючої поверхні; ref - коефіцієнт відбиття від поверхні приймача.

Фактор затінення являє собою відношення затіненої площі приймачів ряду до загальної площі ряду [4]:

$$
s=\frac{H_{s} L_{s}}{H L}=h_{s} l_{s}
$$

і розраховується як добуток значень відносної висоти тіні $h_{s}$ та іiї відносної довжини $l_{s}$ :

$$
\begin{gathered}
h_{s}=\frac{H_{s}}{H}=1-\frac{d \sin \beta+\cos \beta}{\cos \beta+\sin \beta \cos \gamma_{s} / \operatorname{tg} \alpha}, \\
l_{s}=\frac{L_{s}}{L}=1-\left(\frac{\left|\sin \gamma_{s}\right|}{l \lg \alpha}\right) \frac{d \sin \beta+\cos \beta}{\cos \beta+\sin \beta \cos \gamma_{s} / \operatorname{tg} \alpha},
\end{gathered}
$$

де $\gamma_{s}$ - кут азимуту Сонця; $\alpha$ - кут висоти Сонця.

В цих рівняннях використовується відносна відстань між рядами приймачів $d$ та відносна довжина ряду $l$ :

$$
d=\frac{D}{H \sin \beta}, \quad l=\frac{L}{H \sin \beta} .
$$

Розрахунок дифузної та відбитої компонент радіації в умовах взаємного затінення рядами проводився з урахуванням модифікованих коефіцієнтів положення (рис. 2), які визначаються нахилом сонцесприймальної поверхні, відстанню між рядами та розміром тіні $S$ на дану годину. 


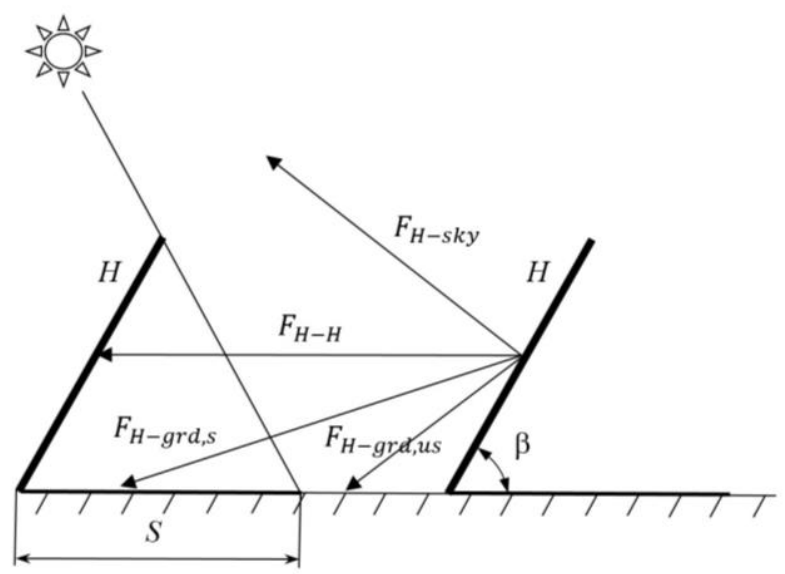

Рис. 2. Коефіціснти положення для фронтальної поверхні приймача.

Fig. 2. View factors of front side of collector.

Коефіцієнти положення поверхні прий- та відносно тильної поверхні приймачів помачів відносно неба $F_{H-s k y}$, затіненої $F_{H-g r d, s}$ та незатіненої $F_{H-\text { grd,us }}$ підстилаючої поверхні пними виразами [2]:

$$
\begin{gathered}
F_{H-s k y}=\frac{H+D+H \cos \beta-\left[H \sin \beta^{2}+D^{2}\right]^{1 / 2}}{2 H}, \\
F_{H-g r d, s}=\frac{\left[2 H \cos \beta+D-S^{2}+H \sin \beta^{2}\right]^{1 / 2}-\left[2 H \cos \beta+D^{2}+H \sin \beta^{2}\right]^{1 / 2}+S}{2 H}, \\
F_{H-g r d, u s}=\frac{H+H \cos \beta+D-S-\left[2 H \cos \beta+D-S^{2}+H \sin \beta^{2}\right]^{1 / 2}}{2 H}, \\
F_{H-H}=\frac{\left[2 H \cos \beta+D^{2}+H \sin \beta^{2}\right]^{1 / 2}+\left[D^{2}+H \sin \beta^{2}\right]^{1 / 2}-2 H \cos \beta+D}{2 H} .
\end{gathered}
$$

Розрахунок надходження сонячної радіації на приймачі при їх килимовому розміщенні проводився 3 врахуванням наступних умов: поверхня приймачів орієнтована на південь; висота приймача $H=2$ м відповідає габаритним розмірам типових пласких сонячних колекторів; діапазон кутів положення $v=5 \div 60^{\circ}$, обмежений умовою $D>0$; діапазон кутів нахилу сонцесприймальної поверхні $\beta=10 \div 60^{\circ}$; цілорічний режим використання перетворювачів сонячної енергії.

Алгоритм розрахунку полягав у визначені за виразами (2) - (5) розмірів тіней на підстилаючій поверхні й поверхні приймачів для кожної години характерної доби місяця при фіксованих кутах положення $v$ та нахилу сонцесприймальних поверхонь $\beta$ із заданих діапазонів. На основі метеорологічних даних
[8] для м. Херсона щодо середньодобових значень сумарної та дифузної радіації розраховувалось погодинне надходження прямої, дифузної та сумарної радіації на горизонтальну поверхню згідно методики [5]. Далі за виразом (1), враховуючи (6) - (9), визначались погодинні значення сонячної радіації на частково затіненій поверхні приймача, за якими розраховувалось добове, місячне та річне надходження енергії $G$.

На рис. 3 представлено сімейство залежностей річних значень сонячної радіації, що надходить на $1 \mathrm{~m}^{2}$ частково затіненої сонцесприймальної поверхні в кліматичних умовах м. Херсона, від кута нахилу поверхні при різних значеннях кута положення, тобто при різних відстанях між рядами.

Як видно з рис. 3 максимум надходження 
сонячної енергії досягається при певних комбінаціях кутів положення та нахилу поверхні, причому, збільшення кута положення $v$ (зменшення відстані між рядами $D$ ) призводить до зменшення відповідного кута нахилу $\beta_{\text {опт }}$, при якому досягається максимум надходження енергії. Значення максимуму питомої енергії при цьому також знижується від 1405,5 до 1210,2 кВт·год/(м².рік) і припадає на діапазон кутів $\beta_{\text {опт }}=19,4 \div 32,5^{\circ}$. Найбільше ж річне надходження сонячної енергії відповідає куту положення $v=5^{\circ}$, при якому практично відсутнє взаємне затінення рядів, що відповідає відстані $D=12,2$ м.

В той же час, аналіз залежностей річного надходження сонячної радіації на $1 \mathrm{~m}^{2}$ поверхні приймача від відстані між рядами при рі- зних $\beta_{\text {опт }}$ (рис. 4) показує, що існує можливість більш компактного розміщення рядів за менших $D$, оскільки кожна залежність виходить на насичення, починаючи $3 v=20^{\circ}$ ( $D$ $=1,9 \div 3,5$ м для різних $\left.\beta_{\text {опт }}\right)$, і при подальшому зменшенні $v$ (збільшенні відстані $D$ ) зростання в надходженні енергії становить менше $3 \%$. Таке значення кута положення відповідає куту висоти Сонця 21 грудня у сонячний полудень, що становить для м. Херсона 20,4, і корелює $з$ результатом, отриманим на основі підходу до визначення відстані між рядами приймачів, запропонованим в роботі [7]. Отже, в якості оптимального кута положення для кліматичних умов м. Херсона рекомендується обрати $v_{\text {опт }}=20,4^{\circ}$.

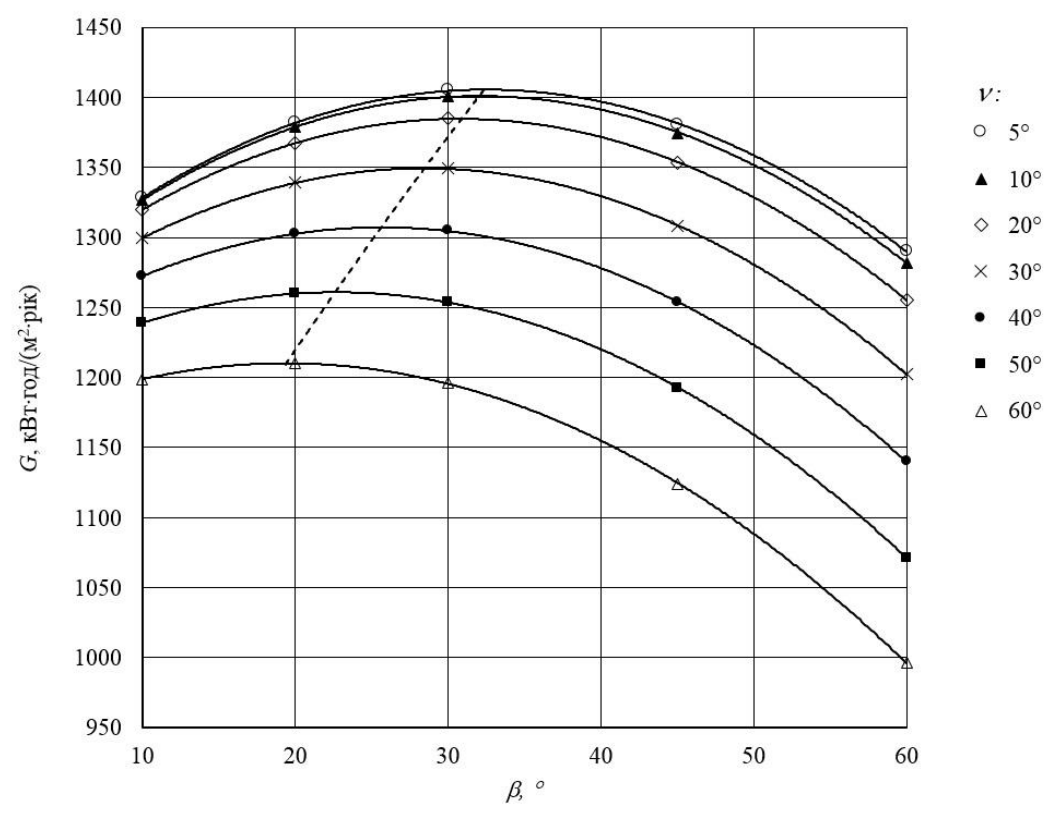

Рис. 3. Залежності річного надходження сонячної радіації на сонцесприймальні поверхні в умовах часткового затінення від кута нахилу поверхонь при різних кутах положення: точки - розрахункові значення; суцільні лінії - апроксимачія поліномом другої степені; пунктирна крива вказує на положення максимумів залежностей.

Fig. 3. Annual solar radiation incited on partially shading collectors plane depending on tilt angle for different position angles: points - calculated values; solid lines - approximation by the second degree polynomial; dashed curve indicates the position of the dependencies maximums.

При $v_{\text {опт }}=20,4^{\circ}$ оптимальний кут нахилу $\beta_{\text {опт }}=30,7^{\circ}$, що забезпечує річне надходження сонячної радіації на $1 \mathrm{~m}^{2}$ поверхні приймачів

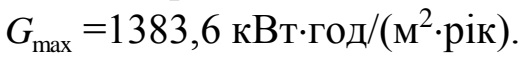

В табл. 1 поряд з рекомендованою наведено інші комбінації кутів положення та нахилу сонцесприймальних поверхонь, при яких досягаються максимуми надходження річної сонячної радіації на 1 м $^{2}$ приймача в умовах часткового затінення, та відповідні значення відстані між рядами. Також представлено коефіцієнти поліномів другої степені, якими апроксимовано залежності на рис. 3 (суцільні криві), що дозволяють визначити річне надходження сонячної радіації на частково затінену поверхню ряду при заданих значеннях кутів $v$ та $\beta$. 


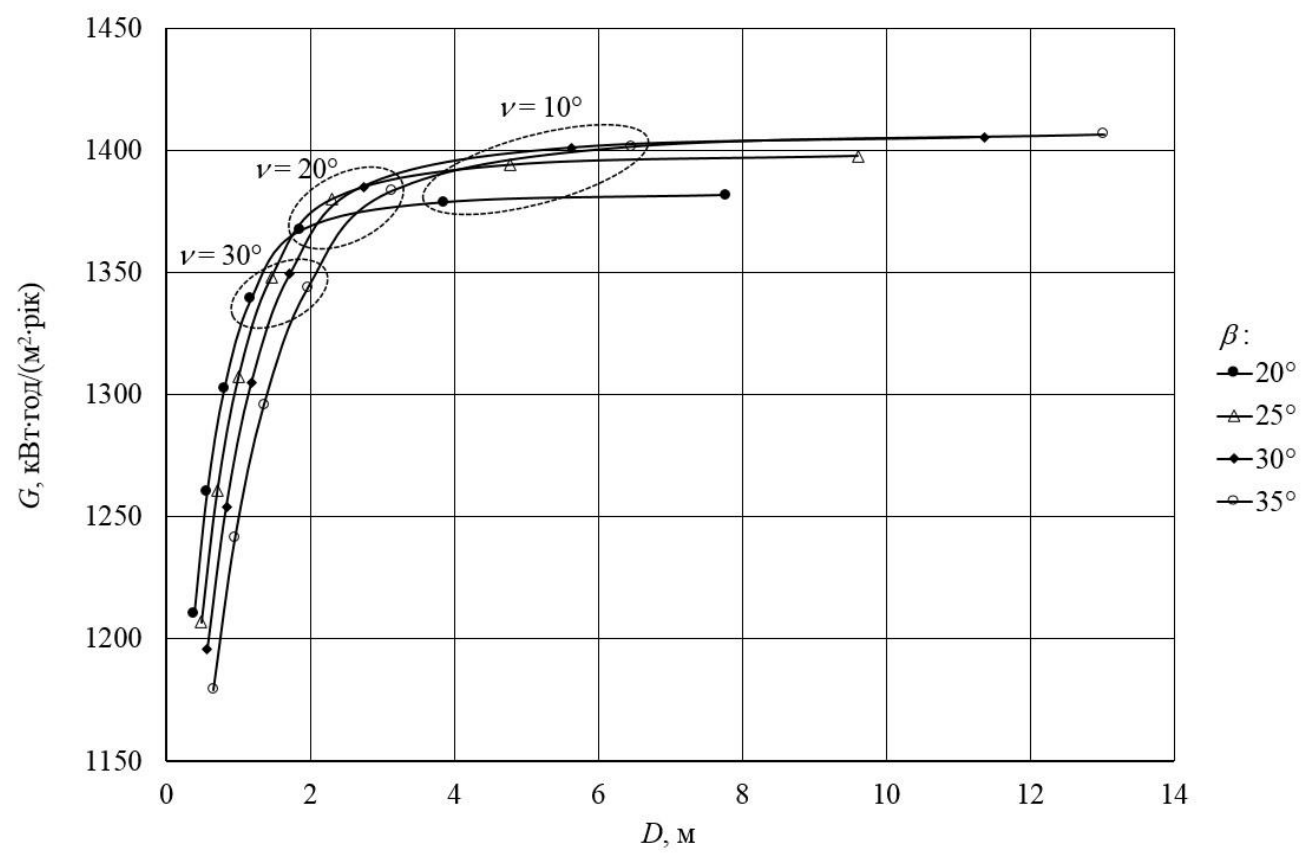

Рис. 4. Залежність річного надходження сонячної радіації на сонцесприймальні поверхні в умовах часткового затінення від відстані між рядами приймачів при різних кутах нахилу: пунктиром виділено точки, щэо відповідають вказаним значенням кута положення.

Fig. 4. Annual solar radiation incited on partially shading collecors plane depending on distance between rows for different tilt angles: dashed lines outline points with similar position angle.

Таблиця 1. Параметри розміщення приймачів сонячної енергії рядами для м. Херсона.

Table 1. Parameters of the multiple row placement of solar energy collectors for Kherson.

\begin{tabular}{|c|c|c|c|c|c|}
\hline \multirow{2}{*}{$v,^{\circ}$} & \multirow{2}{*}{$\beta_{\text {опт }}, \circ$} & \multirow{2}{*}{$D, \mathrm{M}$} & \multicolumn{3}{|c|}{$G=a \beta^{2}+b \beta+c$, кВт.год/(м².рік) } \\
\hline & & & $a$ & $b$ & $c$ \\
\hline 5,0 & 32,5 & 12,2 & $-0,1529$ & 9,9297 & 1244,3 \\
\hline 10,0 & 32,0 & 6,0 & $-0,1527$ & 9,7824 & 1244,2 \\
\hline 20,4 & 30,7 & 2,7 & $-0,1509$ & 9,2526 & 1241,8 \\
\hline 30,0 & 28,4 & 1,6 & $-0,1470$ & 8,3440 & 1230,8 \\
\hline 40,0 & 25,7 & 1,0 & $-0,1420$ & 7,2876 & 1213,7 \\
\hline 50,0 & 22,7 & 0,6 & $-0,1362$ & 6,1880 & 1190,7 \\
\hline 60,0 & 19,4 & 0,4 & $-0,1297$ & 5,0216 & 1161,6 \\
\hline
\end{tabular}

Аналогічні розрахунки було виконано й для інших міст півдня України. Результати цих розрахунків представлено в табл. 2, де наведено оптимальні значення кутів положення та нахилу сонцесприймальних поверхонь, відповідні відстані між рядами та річне надходження сонячного енергії на поверхні приймачів за таких умов. 3 даних табл. 2 слідує, що для розглянутих міст півдня України при цілорічній роботі сонячних приймачів в умовах часткового затінення оптимальні значення кута положення в середньому становлять $20^{\circ}$, а кута нахилу $30,4^{\circ}$.

Таблиця 2. Оптимальні параметри розміщення приймачів сонячної енергії рядами.

Table 2. Optimum parameters of the multiple row placement of solar energy collectors.

\begin{tabular}{|c|c|c|c|c|}
\hline Місто & $v_{\text {опт }}, \circ$ & $\beta_{\text {опт }}, \circ$ & $D, \mathrm{м}$ & $G_{\max }$, кВт·год/(м²·рік) \\
\hline Запоріжжя & 19,2 & 31,1 & 3,0 & 1344,3 \\
\hline Миколаїв & 20,0 & 30,1 & 2,8 & 1380,8 \\
\hline Херсон & 20,4 & 30,7 & 2,7 & 1383,6 \\
\hline Одеса & 20,5 & 29,6 & 2,6 & 1375,8 \\
\hline
\end{tabular}


Висновки. Аналіз результатів розрахунку річного надходження сонячної радіації на частково затінені сонцесприймальні поверхні при килимовому розміщенні приймачів дозволив встановити, що залежності питомої енергії $G$ від кута нахилу поверхні $\beta$ при фіксованих кутах положення $v$ мають вигляд кривих $з$ максимумом при певному значенні $\beta_{\text {опт }}$ та описуються поліномами другої степені.

На прикладі метеорологічних даних для м. Херсона визначено, що для $v=5 \div 60^{\circ}$ максимальне річне надходження сонячної радіації на 1 м $^{2}$ сонцесприймальної поверхні спостерігається в порівняно вузькому діапазоні кутів нахилу $\beta_{\text {опт }}=19,4 \div 32,5^{\circ}$. Для вказаного діапазону кутів положення $v$ отримано вирази, що дозволяють в зручний спосіб без проведення громіздких розрахунків визначити річну питому енергію, яка надходить на одиницю площі затіненого ряду при заданому куті нахилу $\beta$.

Показано, що в якості оптимального кута положення $v_{\text {опт }}$ доцільно прийняти кут висоти Сонця у сонячний полудень 21 грудня. Для умов м. Херсона $v_{\text {опт }}=20,4^{\circ}$, а відповідне йому значення кута нахилу поверхні $\beta_{\text {опт }}=30,7^{\circ}$, що забезпечує річне надходження сонячної радіації $G_{\max }=1383,6$ кВт.год $/\left(\mathrm{м}^{2} \cdot\right.$ рік $)$.

Розрахунки кутів $v_{\text {опт }}$ та $\beta_{\text {опт }}$ для низки інших міст півдня України, як-то Одеса, Миколаїв та Запоріжжя, показали, що при цілорічній роботі сонячних приймачів в умовах часткового затінення оптимальні значення кута положення змінюються від $19,2^{\circ}$ для Запоріжжя до $20,5^{\circ}$ для Одеси і в середньому становить $20^{\circ}$, в той час як середній оптимальний нахил сонцесприймальної поверхні складає $30,4^{\circ}$.

1. Al-Turki A.M., Elsayed M.M. Long term performance of a shaded collector field. International Journal of Solar Energy. 1990. Vol. 8. Pp.187-202. doi: 10.1080/01425919008909722.

2. Appelbaum J. The role of view factors in solar photovoltaic fields. Renewable and Sustainable Energy Reviews. 2018. No. 81. Pp. 161-171. doi: 10.1016/j.rser.2017.07.026.

3. Aronescu A., Appelbaum J. Design optimization of photovoltaic solar fields-insight and methodology. Renewable and Sustainable Energy Reviews. 2017. No. 76. Pp. 882-893. doi: 10.1016/j.rser.2017.03.079.

4. Bany J., Appelbaum J. The effect of shading on the de- sign of a field of solar collectors. Solar Cells. 1987. No. 20. Pp. 201-228. doi: 10.1016/0379-6787(87)90029-9.

5. Duffie J.A., Beckman W.A. Solar Engineering of Thermal Processes. Hoboken: John Wiley \& Sons. Inc. 2013.910 p.

6. Elsayed M.M., Al-Turki A.M. Calculation of shading factor for a collector field. Solar Energy. 1991. No. 6. Vol. 47. Pp. 413-424. doi: 10.1016/0038-092X(91)90109-A.

7. Fathi N.Y., Samer A. View Factors of Flat Solar Collectors Array in Flat, Inclined, and Step-Like Solar Fields. Journal of Solar Energy Engineering. 2016. Vol. 138. Pp. 061005-1-8. doi: $10.1115 / 1.4034549$.

8. Power data access viewer. [Електронний ресурc]. URL: https://power.larc.nasa.gov/data-access-viewer/ (дата звернення: 15.06.2019).

9. Weinstock D., Appelbaum J. Optimal Solar Field Design of Stationary Collectors. Journal of Solar Energy Engineering. 2004. Vol. 126. Pp. 898-905. doi: 10.1115/1.1756137.

10. Weinstock D., Appelbaum J. Optimization of Solar Photovoltaic Fields. Journal of Solar Energy Engineering. 2009. Vol. 131. Pp. 031003-1-9. doi: 10.1115/1.3142705.

11. Авезов Р.Р. и др. Системы солнечного тепло- и хладоснабжения. М. Стройиздат. 1990. 328 с.

\section{REFERENCES}

1. Al-Turki A.M., Elsayed M.M. Long term performance of a shaded collector field. International Journal of Solar Energy. 1990. Vol. 8. P.187-202. [in English]. doi: $10.1080 / 01425919008909722$.

2. Appelbaum J. The role of view factors in solar photovoltaic fields. Renewable and Sustainable Energy Reviews. 2018. No. 81. Pp. 161-171. [in English]. doi: 10.1016/j.rser.2017.07.026.

3. Aronescu A., Appelbaum J. Design optimization of photovoltaic solar fields-insight and methodology. Renewable and Sustainable Energy Reviews. 2017. No. 76. Pp. 882-893. [in English]. doi: 10.1016/j.rser.2017.03.079.

4. Bany J., Appelbaum J. The effect of shading on the design of a field of solar collectors. Solar Cells. 1987. No. 20. Pp. 201-228. [in English]. doi: 10.1016/0379-6787(87)90029-9.

5. Duffie J.A., Beckman W.A. Solar Engineering of Thermal Processes. Hoboken: John Wiley \& Sons. Inc. 2013. 910 p. [in English].

6. Elsayed M.M., Al-Turki A.M. Calculation of shading factor for a collector field. Solar Energy. 1991. No. 6. Vol. 47. Pp. 413-424. [in English]. doi: 10.1016/0038-092X(91)90109-A.

7. Fathi N.Y., Samer A. View Factors of Flat Solar Collectors Array in Flat, Inclined, and Step-Like Solar Fields. Journal of Solar Energy Engineering. 2016. Vol. 138. Pp. 061005-1-8. [in English]. doi: 10.1115/1.4034549.

8. Power data access viewer. [Electronic resource]. URL: https://power.larc.nasa.gov/data-access-viewer/ (Applying date: 15.06.2019). [in English].

9. Weinstock D., Appelbaum J. Optimal Solar Field Design of Stationary Collectors. Journal of Solar Energy Engineering. 2004. Vol. 126. Pp. 898-905. [in English]. doi: $10.1115 / 1.1756137$.

10. Weinstock D., Appelbaum J. Optimization of Solar Photovoltaic Fields. Journal of Solar Energy Engineering. 2009. Vol. 131. Pp. 031003-1-9. [in English]. doi: 10.1115/1.3142705.

11. Avezov R.R. $i \quad d r$. Sistemy solnechnogo teplo- i khladosnabzheniya. [Solar heat and cold supply systems]. Moscow. Stroiizdat. 1990. 328 p. [in Russian]. 


\section{ОПТИМИЗАЦИЯ РАЗМЕЩЕНИЯ ПРИЕМНИКОВ СОЛНЕЧНОЙ ЭНЕРГИИ РЯДАМИ ДЛЯ КЛИМАТИЧЕСКИХ УСЛОВИЙ ЮГА УКРАИНЫ}

Е.В. Андронова, канд. техн. наук, В.В. Курак, канд. техн. наук

Херсонский национальный технический университет, 73008, Бериславское шоссе, 24, г. Херсон, Украина.

Максимальное поступление солнечной энергии на поверхность приемников при их размещении параллельными рядами обеспечивается минимизацией затенения одного ряда другим. Существующие методики расчета поступления солнечной радиачии на приемники в условиях затенения рядами не дают универсального ответа на вопрос оптимального взаимного размещения рядов солнцевоспринимающих поверхностей и требуют привлечения данных относительно условий солнечной инсолячии для конкретной местности. Поскольку методики, базируюшиеся на расчете абсолютных показателей поступления энергии на поле приемников, требуют, кроме энергетических, дополнительных критериев оптимизации, то целесообразно ориентироваться на показатели поступления солнечной радиации на единииу площади затеняемой солнщевоспринимающей поверхности. Целью данной работы является расчет поступления солнечной радиачии на единииу площади солнцевоспринимающей поверхности частично затененного ряда и определение оптимальных параметров размещения приемников параллельными рядами для климатических условий юга Украиныл. Представлена методика расчета поступления солнечной энергии на частично затененные ряды, учитывающая прямую, диффузную, отраженную от подстилающей поверхности и наклонной поверхности приемников солнечную радиачию. Для климатических условий г. Херсона получень выражения, позволяющие удобно без проведения громоздких расчетов определить годовую удельную энергию, приходящую на единииу площади затененного ряда при заданном угле наклона поверхности и расстоянии между рядами. Показано, что в качестве оптимального угла положения, определяющего расстояние между рядами приемников, иелесообразно принять угол высоты Солниа в солнечный полдень 21 декабря. Определен оптимальный угол наклона поверхности приемников, обеспечивающий максимальное годовое поступление солнечной радиации на единииу площади солцевоспринимающей поверхности затененного ряда.

Рассчитаны параметры размещения приемников параллельными рядами для ряда других городов юга Украины и определены средние значения оптимальных углов положения и наклона солнцевоспринимающих поверхностей. Библ. 8, табл. 8, рис. 4.

Ключевые слова: солнечная радиация, затенение, угол наклона, расстояние между рядами.

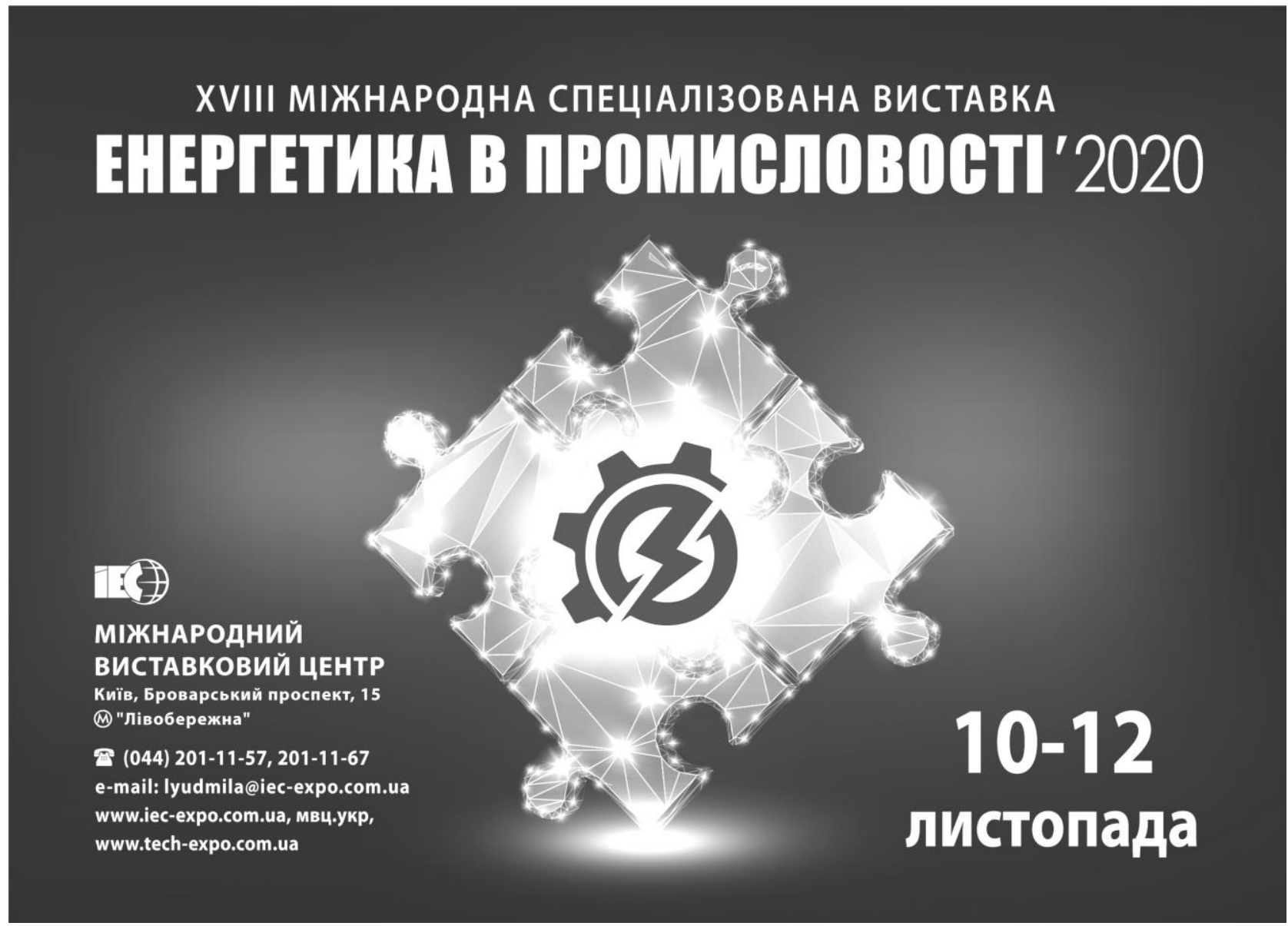

